\section{Expression of fibroblast cells after extraction of wistar rat teeth after topical application of okra fruit (Abelmoschus esculentus) gel}

\author{
Muhammad Luthfi, ${ }^{1}$ Wisnu Setyari \\ Juliastuti, ${ }^{1}$ Yuniar Aliyah Risky, ${ }^{2}$ \\ Elvina Hasna Wijayanti, ${ }^{2}$ \\ Aisyah Ekasari Rachmawati, ${ }^{2}$ \\ Nidya Pramesti Olifia Asyhari ${ }^{2}$
}

${ }^{1}$ Department of Oral Biology; ${ }^{2}$ Faculty

of Dental Medicine, Airlangga

University, Surabaya, Indonesia

\begin{abstract}
Background: Tooth extraction is a dental procedure for removing a teeth from the alveolar bone socket. The tooth extraction process causes damage to hard tissue and soft tissue, so the body will respond physiologically to heal the wound. The wound healing process is divided into several phases, one of which is the proliferation phase of fibroblasts, which is one of the most important phases in the process of wound healing. Okra fruit contains saponins, tannins, flavonoids and alkaloids that have antiinflammatory, antibacterial, antioxidant effects, and can stimulate angiogenesis so to accelerate the process of wound healing.

Objective: to prove that the administration of okra fruit extract can accelerate the process of wound healing after extraction in the teeth of Wistar rats through increased expression of fibroblast cells.
\end{abstract}

Methods: 18 Wistar rats were divided into 2 groups; control group and treatment group. The treatment group received a $30 \%$ okra fruit extract. The number of fibroblasts was calculated statistically using One Way ANOVA and Tukey HSD.

Results: The results showed that the expression of control group fibroblast cells on day $3(19.00 \pm 2.0)$, day $5(21.67 \pm 2.08)$, day $7(24.00 \pm 2.00)$, whereas in the treatment group on day $3(24.00 \pm 1.00)$, day 5 $(29.00 \pm 2.00)$, day $7(30.00 \pm 1.53)$. Anova test between groups showed a significant difference with P-value 0.006 .

Conclusion: $30 \%$ okra fruit extract can increase fibroblast expression in wound healing process after extraction of Wistar rat teeth.

\section{Introduction}

Tooth extraction is a dental procedure for removing teeth from the alveolar bone socket. The tooth extraction process causes damage to hard and soft tissue, and body will respond physiologically to heal the wound. ${ }^{1}$ The process of wound healing after tooth extraction is a complex and dynamic process that aims to restore the original condition of the network. This process involves epithelial regeneration and the formation of connective tissue, and follows the general principles that apply to wound healing in all tissues. The wound healing process is divided into several phases, namely the inflammatory phase, the proliferation phase, and the maturation/remodeling phase. The proliferation phase includes re-epithelialization, angiogenesis, granulation tissue formation, and collagen deposition, starting on the fourth day for up to two weeks after injury. ${ }^{2}$ Prevention on post-extraction wound healing complications is the most important factor, because when the wound does not heal immediately, it will have an impact on public health and generate losses due to the physical and psychological deficiencies it can causes, and even death. ${ }^{3}$

Although there are several treatment options on the market for wound healing, many of them have high costs because they require long treatment. ${ }^{4}$ Pharmaceutical technology has recently been giving more attention to natural ingredients that can be used in wound healing. Natural ingredients are chosen because they are relatively safer to use compared to the use of chemicalbased drugs. $^{5}$

Okra fruit is a fruit that is widely available in Indonesia and is used by most people as a vegetable in daily food. Okra fruit extract (Abelmoschus esculentus) can be used as an alternative treatment because it has various medicinal properties, such as antidiabetic, antioxidant, antiplasmodial, antibacterial, anticancer, analgesic, antidiarrheal, and anti-inflammatory properties. ${ }^{6}$ The active ingredients contained in okra fruit extract include saponins, tannins, flavonoids, and alkaloids. ${ }^{7}$ The antioxidant content in okra fruit is quercetin, which can protect the body from certain types of degenerative diseases. The saponin functions as an antibacterial and can stimulate angiogenesis. Other studies have reported that flavonoids, contained in the okra fruit as well, have anti-inflammatory properties, they act as moderator type III collagen sentiment, and also as phospholipase inhibitors. ${ }^{8}$ Flavonoids can also modulate oxidative burst in neutrophils, which can cause a decrease in Reactive Oxygen Species (ROS), which in turn can accelerate the process of wound healing. ${ }^{9}$ Based on the above descriptions of the properties of natural ingredients such as okra, there has been
Correspondence: Muhammad Luthfi, Department of Oral Biology, Faculty of Dental Medicine - Airlangga University, Jl. Prof. Dr. Moestopo no. 6-8,60131, Surabaya, Indonesia.

Tel.: +62 81357898957

E-mail: m.luthfi@fkg.unair.ac.id

Key words: Tooth extraction, wound healing, fibroblasts, okra fruit.

Contributions: ML: Study conception, study design, intelectual content, literature research, data acquisition, data analysis, manuscript review, guarantor. WSJ: Study concept, clinical studies, experimental studies, data analysis, manuscript review. YA, RE, HW, AER, NPOA: data interpretation, statistical analysis, manuscript preparation, manuscript editing.

Conflict of interest: The authors declare no conflicts of interest

Funding: None.

Acknowledgements: The author would like to thank all those who contributed to this research and to Research Centre Faculty of dental Medicine Universitas Airlangga.

Clinical trials: In this study conducted pre clinical trials with animals.

Conference presentation: International Conference on Infectious Diseases, Biothreats, and Military Medicine (INSBIOMM).

Received for publication: 17 February 2020. Accepted for publication: 1 July 2020.

This work is licensed under a Creative Commons Attribution-NonCommercial 4.0 International License (CC BY-NC 4.0).

COpyright: the Author(s), 2020

Licensee PAGEPress, Italy

Infectious Disease Reports 2020; $12($ s1):8726 doi:10.4081/idr.2020.8726

much research from academics that explores various new strategies to accelerate wound healing, including the use of plants and natural products. Inthis study we want to analyze the wound healing activity of okra (Abelmoschus esculentus) fruit extract in Wistar rats.

\section{Materials and Methods}

This research is an in vivo laboratory experimental study using a post-test only control group designs that have been tested 
ethical clearance in Airlangga University Faculty of Dental Medicine Health Research Ethical Clearance Commission Number: 155/HRECC. FODM/VII/2018.

\section{Samples}

The samples used in this study were Wistar rats obtained from the Biochemistry Laboratory Unit of the Medical Faculty of Airlangga University. The inclusion criteria were male Wistar rats aged 2-3 months weighing 100-150 grams, while Wistar rats that do not show active movements, had decreased appetite and diarrhea were excluded from the test. The samples that met the inclusion criteria were divided into two groups: the treatment group was given $0.1 \mathrm{~mL} 30 \%$ okra fruit extract in gel on the tooth extraction socket, while the control group was given a gel that did not contain okra fruit.

\section{Okra (Abelmoschus esculentus) extract making procedure}

Okra fruit extract derived from fresh okra fruit of Materia Medika Batu, Malang. Fresh Okra fruit is dried in a drying oven until a constant weight is reached. Dried fruit is then ground into powder. A total of $2 \mathrm{~g}$ of powder was extracted with $20 \mathrm{~mL}$ of $70 \%$ ethanol in a ratio of $1: 10(\mathrm{w} / \mathrm{v})$ during the maceration period (24 hours) at room temperature. The mixture of solvent and soaked powder is filtered through filter paper, then concentrated to $1 \mathrm{~mL}$ with a rotary evaporator and diluted with 5\% dimethyl sulfoxide (DMSO) at a ratio of 1:1 (v/v), and stored at $-20^{\circ} \mathrm{C}$ until used more continued.

\section{Gel okra fruit 30\% extract making procedure}

Carboxy Methyl Cellulose Sodium (CMC $\mathrm{Na} 3 \%$ ) was used as the base material for the gel. CMC Na $3 \%$ is obtained by dissolving CMC Na $3 \%$ powder with $100 \mathrm{~mL}$ of warm water in the mortar. The powder is added gradually and flat on the entire surface of the water so that it can be dispersed. We let it stand for 10-15 minutes so to obtain a soft, transparent, gel-textured mass. Then stir with the stamper until the gel becomes homogeneous and slowly add $40 \mathrm{~mL}$ of water so that the volume becomes $100 \mathrm{~mL}$. Making 30\% okra fruit extract gel required $3 \mathrm{ml}$ okra fruit extract and $7 \mathrm{~mL} \mathrm{CMC} \mathrm{Na} 3 \%$.

\section{Preparation experimental animals}

Male Wistar rats aged 2-3 months and weighing $100-150 \mathrm{mg}$ were placed in the same cage at a temperature of $25 \pm 2^{\circ} \mathrm{C}$. They were given pellet food and standard distilled water ad libitium for 7 days before the experiment started. ${ }^{10}$ This procedure was done to reduce stress and obtain uniformity (homo- geneity) of Wistar rats conditions.

\section{Experimental animal treatment}

After adjusting for 7 days, the 18 Wistar rats were divided into 2 groups (control and treatment). Wistar rats in each group were anesthetized by peritoneal injection using a $0.1 \mathrm{~mL}$ ketamine combination per rat. After 1-1.5 hours from the injection, we extracted the mandibular left incisor using a scalpel and needle holder, making sure there were no leftover teeth in the tooth socket. The tooth socket was then irrigated using saline solution. ${ }^{11}$ In the control group after extraction the tooth socket was given $0.1 \mathrm{~mL}$ CMC Na 3\% gel, while in the treatment group after extraction Wistar rats were immediately given $0.1 \mathrm{~mL}$ okra fruit extract on one apical third tooth socket.

\section{Experimental animal euthanasia and mandibular extraction in the} area of the tooth extraction socket

Wistar rats were killed on the $3^{\text {rd }}, 5^{\text {th }}$ and $7^{\text {th }}$ day after tooth extraction with a lethal dose of ketamine via intraperitoneal injection (minimum 4 times the anesthetic dose, about $0.4 \mathrm{~mL} / \mathrm{kgBB}$ ). Mandibular were taken from the temporo mandibular joint, then Wistar rats were buried according to the ethics of experimental animals. Mandibules in the incisor area were cut vertically, and then preparation techniques continued in all groups with the paraffin method. ${ }^{12}$

\section{HPA examination}

Samples obtained from Wistar rat tooth socket after extraction on days 3, 5 and 7 were analyzed histologically for expression of fibroblast cells after being fixed in $10 \%$ formalin at room temperature for at least 24

Table 1. Mean and standard deviation of fibroblast cells after $t$-test.

\begin{tabular}{lcccc} 
Groups & Samples & \multicolumn{3}{c}{ Mean \pm standard deviation } \\
& & Day 3 & Day 5 & Day 7 \\
Control & 3 & $19.00 \pm 2.00$ & $21.67 \pm 2.08$ & $24.00 \pm 2.00$ \\
Treatment & 3 & $24.00 \pm 1.00$ & $29.00 \pm 2.00$ & $30.00 \pm 1.53$ \\
\hline
\end{tabular}

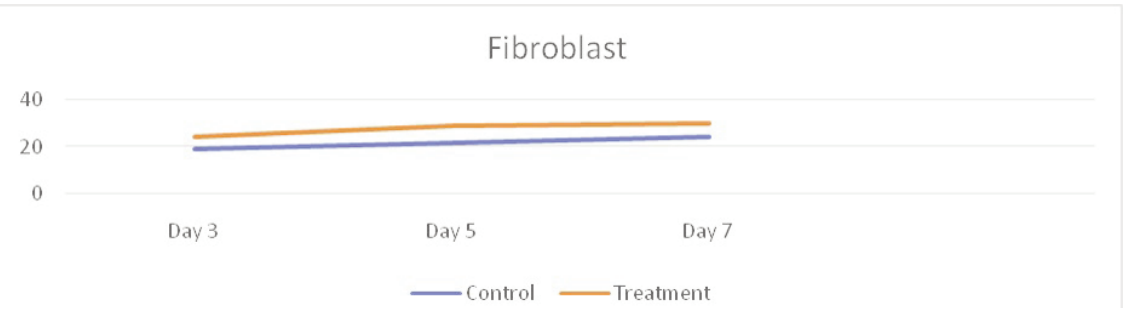

Figure 1. Graph of average number of fibroblast cells on days 3, 5, and 7 in the control group and the treatment group. HE staining results were seen in a microscope with $400 \mathrm{x}$ magnification. hours. After fixation, they were dehydrated in ethanol, cleaned with xylene, and carried out in paraffin blocks with a thickness of 6 $\mathrm{mm}$. Then they were deparafinated with xylene, stained with hematoxylin and eosin (HE) and then the expression of fibroblast cells was analyzed under a microscope with a magnification of $400 \mathrm{X}$.

\section{Statistical analysis}

Statistical analysis were then carried out on the data obtained. The Kolmogorovsmirnov test was carried out to test the distribution and then the homogeneity test was performed using the Levene Test. If the distribution were normal and the data homogeneous we then proceded with the One Way ANOVA test, followed by the Tukey HSD test if there are significant differences. If the data were normally distributed and the data not homogeneous, the test performed was the Kruskall-Wallis test and if there were significant differences followed by the Mann-Whitney test.

\section{Results}

Based on research that has been done using 18 samples of Wistar rats (Rattus norvegicus) divided into 2 groups, namely the control group $(\mathrm{K})$ and the treatment group (P). After treatment each group was killed to count fibroblast cells and angiogenesis on days 3, 5, and 7. Examination of fibroblast cells was carried out under a light microscope at 400x magnification. Based on calculations, the results are as follows:

The following is a graphical picture of the average number of fibroblast cells in the $\mathrm{K}$ and $\mathrm{P}$ groups on the $3^{\text {rd }}, 5^{\text {th }}$ and $7^{\text {th }}$ day (Figure 1). 
The calculation result of the number of fibroblasts in the tooth extraction sockets can be seen in Table 1 and Figure 2. On the $3^{\text {rd }}$ day, the calculation of the number of fibroblast cells was obtained on average in the control group was 19 , on the $5^{\text {th }}$ day was 21.67 , and on the $7^{\text {th }}$ day was 24 .

The ANOVA statistical test result on fibroblast cells and in Table 2 show the value of $\mathrm{P}=0.006(\mathrm{P}<0.05)$ which means that there are significant differences in the number of fibroblast cells from each treatment group. To find out the significant differences in a group, the Tukey HSD test was carried out with $\alpha=0.05$.

The results of the Tukey HSD test obtained and showed that there were significant differences between control groups and the treatment groups in the number of fibroblasts cells on day 3, 5, and 7 (Table 3).

The results of the Tukey HSD test showed that there were significant differences in the number of fibroblast cells in the treatment group between day 3 compared to day 5 , but it did not show a significant difference on day 5 compared to day 7 .

The following is an overview of HPA expression of fibroblast cells in sockets after tooth extraction in the control group and treatment group as follows (Table 4).

\section{Discussion}

On the histological examination of the results obtained, it was generally found that the mean number of fibroblast cells in the treatment group that was given a $30 \%$ okra fruit extract gel after tooth extraction increased on day 3, 5 and 7 compared to the control group. Based on statistical tests, there were significant differences in the treatment group on day 3 compared to day 5 and day 7 , while on day 5 compared to day 7 there were no significant difference. Meanwhile, the statistical test between the control group and the treatment group on the same day always showed significant differences.

This is because many okra fruit extracts contain steroids, tannins, thiamin, amino acids, oxalic acid, and niacin. Besides okra fruit extract also contains some important chemical compounds, namely flavonoids. ${ }^{14}$ Okra (Abelmoschus esculentus) has an antioxidant and anti-inflammatory role. ${ }^{15,16}$ It contains polyphenols and polysaccharides found in okra seeds and okra fruit skin, also contains flavonoids, isoquercetin, and the quercetin-3-O-gentiobiose contained in okra seeds has an antioxidant effect. ${ }^{17}$ Phytochemical analysis of herbal plants including okra, highlighted the presence of elements such as flavonoids, phenols and tannins. Tannins are phenolic compounds that are usually used in wound healing, while the astringent content serves to stimulate contractions and accelerate the process of epithelialization in the formation of granulation tissue and the remodeling phase. ${ }^{18}$ Talekar et al. ${ }^{19}$ says that the extract content of the plant can accelerate the wound healing process by proliferation and mobilization of fibroblasts and keratiocytes,

Table 2. The results of Anova test between the treatment group on days 3, 5, and 7.

\begin{tabular}{|c|c|c|c|c|c|c|}
\hline \multirow{3}{*}{ Fibroblast } & \multicolumn{6}{|c|}{ ANOVA } \\
\hline & \multicolumn{2}{|c|}{ Sum of squares } & \multirow{2}{*}{ df } & \multirow{2}{*}{$\begin{array}{c}\text { Mean square } \\
\qquad 33,444\end{array}$} & \multirow{2}{*}{$\begin{array}{c}\mathrm{F} \\
13,682\end{array}$} & \multirow{2}{*}{$\begin{array}{l}\text { Sig. } \\
0,006\end{array}$} \\
\hline & Between groups & 66,889 & & & & \\
\hline & Within groups & 14,667 & 6 & 2,444 & & \\
\hline & Total & 81,556 & 8 & & & \\
\hline
\end{tabular}

Table 3. The results of the Tukey HSD test between the control group and the treatment group on days 3,5 , and 7 .

\begin{tabular}{lcccc} 
& \multicolumn{3}{c}{ Treatment groups } \\
& Treatment groups number of fibroblast cells & \\
& Day & 3 & 5 & 7 \\
Control & 3 & $0.018^{*}$ & & \\
Groups & 5 & & $0.012^{*}$ & \\
\hline
\end{tabular}

Table 4. The results of the Tukey HSD test between the treatment groups on days 3, 5, and 7.

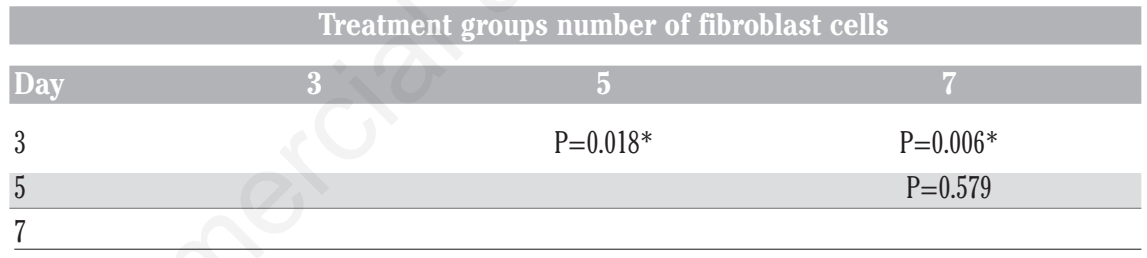
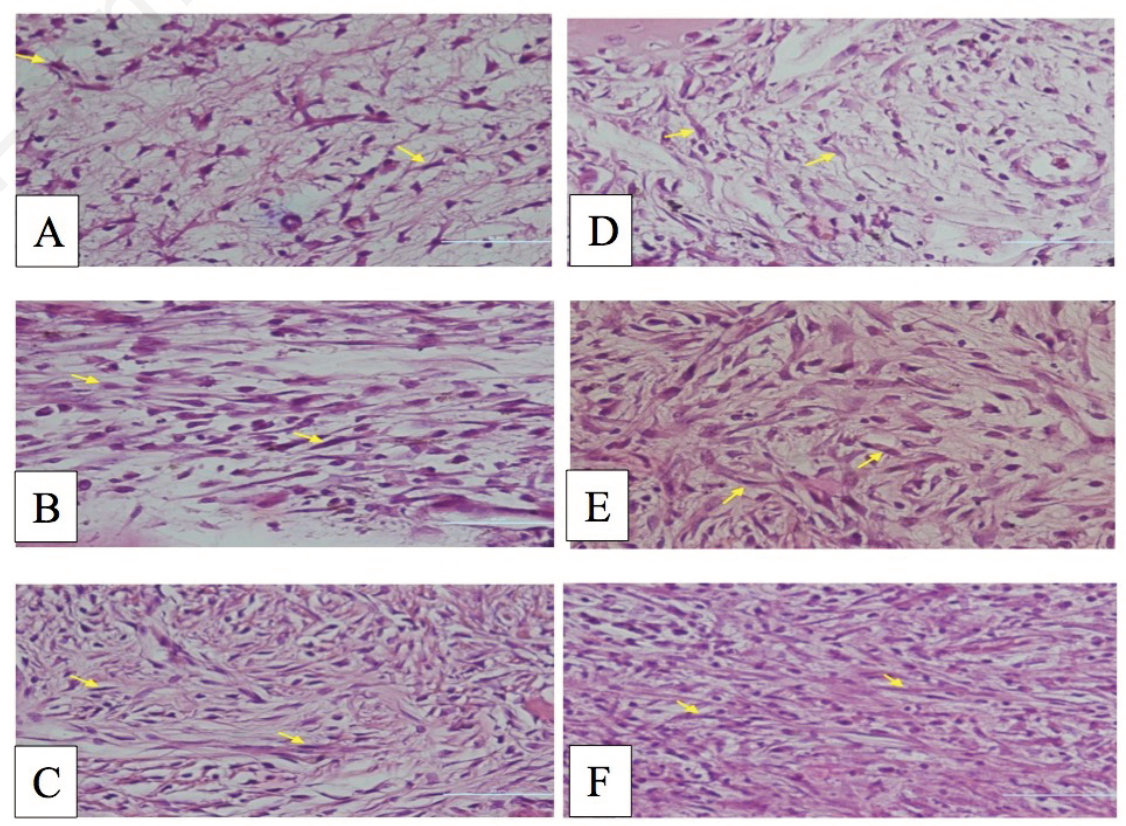

Figure 2. Description of HPA fibroblast cells in post tooth extraction sockets in group (a) control of day 3, (b) control of day 5, (c) control of day 7, (d) treatment of day 3, (e) treatment of day 5, and (f) 7 th day treatment. Arrow points to fibroblast cells with $\mathrm{HE}$ staining, 400x magnification. 
and promote angiogenesis at the wound site.

In this study on day 3 and 5 we observed an increase of fibroblast cells, because one of the roles of flavonoids contained in okra is to reduce the release of prostaglandins and proinflammatory mediators by inhibiting the cyclooxygenase enzyme. ${ }^{20}$ In addition, flavonoids can also reduce oxidative stress by regulating the activity of NF-kB, so that the increase in proinflamator cytokines can be reduced. The decrease causes inducible Nitric Oxide Synthase (iNOS) activity to be suppressed so that it can accelerate the wound healing process..$^{21} \mathrm{~A}$ previous study by Pang et al. found that low-dose flavonoids alone were able to stimulate the expression of TGF- $\beta$ growth factor which was able to increase TGF- $\beta$ levels until the 7 th day and in the wound healing process which is a stimulator of fibroblast cells. ${ }^{22}$

\section{Conclusions}

Giving an okra 30\% fruit extract gel in the tooth socket after extraction can increase fibroblast cell proliferation.

\section{References}

1. Ngangi RS, Mariati NW, Hutagalung BSP. Gambaran pencabutan gigi di balai pengobatan rumah sakit gigi dan mulut Universitas Sam Ratulangi tahun 2012. EG 2013;1:81-7.

2. Gonzales AC, Andrade ZA, Costa TF, Medrado AR. Wound healing - a literature review. An Bras Dermatol 2016;91:614-20.

3. Bayat A, Mcgrouther DA, and Ferguson MWJ. Skin scarring. BMJ 2013;326:88-92.
4. Ferreira E, Lucas R. Rossi LA, Andrade D. Curativo do paciente queimado: uma revisã o de literatura. Rev Esc Enferm USP 2003;37:44-51.

5. Auliyah, NS. Pengaruh Ekstrak Teripang Pasir terhadap Jumlah Sel Fibroblas pada Soket pasca Pencabutan Gigi Cavia cobaya. Oral surg Dent J 2015; 4:07:1-6.

6. Nesa L, Islam M, Alam B, et al. Analgesic, Anti-inflammatory and CNS Depressant Activities of the Methanolic Extract of Abelmoschus esculentus Linn. Seed in Mice. Br J Pharm Res 2014;4:849-60.

7. Bello HS, Mustapha A, Isa MA, Rahila TC. The invitro antibacterial activity of Okra (Abelmoschus esculentus) against some selected bacteria from Maiduguri, North Eastern Nigeria. Int J Biosci Nanosci 2015;2:84-8.

8. Kumar D, Tony D, Kumar A, et al. A review on: Abelmoschus esculentus (Okra). Int Res J Pharm App Sci 2013;3:129-32.

9. Soemarie, Yulistia B. Uji aktivitas antiinflamasi kuersetin kulit bawang merah (Allium cepa L.) pada mencit putih jantan (Mus musculus). Jurnal Ilmiah Ibnu Sina 2016;1:163-72.

10. Talubmook C, Nopparat Buddhakala. Bioactivities of extracts from Tinospora crispa stems, Annona squamosa leaves, Musa sapientum flowers, and Piper sarmentosum leaves in diabetic rats. IJOART 2013;2:14.

11. Gunawan F, Sularsih, Soemartono. Perbedaan kitosan berat molekul rendah dan tinggi terhadap jumlah sel limfosit pada proses penyembuhan luka pencabutan gigi. Denta Jurnal Kedokteran Gigi 2015;9:114-22.

12. Sudiana, IK. Pewarnaan apoptosis. In: Teknologi Ilmu Jaringan dan Imunohistokimia. Jakarta: Sagung Seto
2004: 9-47.

13. Sugiyono. Metode penelitian pedidikan pendekatan kuantitatif, kualitatif, dan R\&D. Bandung: Alfabeta; 2008.

14. Roy A, Shrivastava SL, Mandal SM. Functional properties of Okra Abelmoschus esculentus L. (Moench): traditional claims and scientific evidences. Plant Sci 2014;1:121-30.

15. Xia F, Zhong Y, Li M, et al. Antioxidant and anti-fatigue constituents of okra. Nutrients 2015:8846-7.

16. Solomon S, Muruganantham N, Senthamilselvi MM. Anti-oxidant and anti-inflammatory activity of Abelmoschus esculentus (flowers). IAJPS 2016;3:605.

17. Athira C, Jayaraman JA. review on: a pharmacological properties of Abelmoschus esculentus. World J Pharm Res 2018;7:165-67.

18. Bin Li, Wang James HC. Fibroblasts and myofibroblasts in wound healing: force generation and measurement. J Tissue Viab 2011;20:108-20.

19. Talekar YP, Apte KG, Paygude SV, et al. Studies on wound healing potential of polyherbal formulation using in vitro and in vivo assays. J Ayurveda Integr Med 2017;8:73-81

20. Rathee P, Chaudhary H, Rathee Sushila., et al. Mechanism of action of flavonoids as anti-inflammatory agents: a review. Inflamm Allergy Drug Targets 2009;8:229-35.

21. Qing, C. The molecular biology in wound healing \& non-healing wound. Chin J Traumatol 2017; 20:189.

22. Pang $\mathrm{X}$, Bao D, Wang J, Liu $\mathrm{H}$. Protective effect of quercetin against oxidative stress-induced cytotoxicity in rat pheochromocytoma (PC-12) cells. Molecules 2017; 22:1122. 